\title{
Learning Domain Covered by the West African Senior School Certificate Examination Questions: Implication for Teaching-Learning Process
}

\author{
Daniel Orifamah \\ School of Physical Science Education, Imo State University, Owerri. Nigeria.
}

\begin{abstract}
The study investigated the learning domain covered by the West African Senior School Certificate Examinations (WASSCE) in English, June 2020; the aim was to find out the extent of each category of the cognitive (lower, mid, and upper) domain covered by the test, a case study research design was adopted in data collection, data analysis was done using percentage frequency of each category and chi-square test, the findings showed that the percentage frequency of cognitive domain tested was not in consonance with the expected, the study recommended among others the coverage of the three categories of the cognitive domain to maintain the expected standard of Senior School Certificate holders in West Africa and globally.
\end{abstract}

Keywords: learning domains, cognitive domain, category, coverage.

DOI: $10.7176 / \mathrm{JEP} / 12-32-10$

Publication date: November $30^{\text {th }} 2021$

\section{Introduction}

The teachers' work of teaching the learners is guided by the course or subject's curriculum in addition to the standard or quality of questions set by the various examination bodies responsible for testing and certification of the learners at the end of the course or subject duration. Each course curriculum is guided by the learning domains in the subject area. There are three main learning domains that every teaching pedagogy aims at achieving. These are the Cognitive domain, Affective domain, and psychomotor domain (Armstrong, 2010). The fourth learning domain known as; Psycho-productive is not very much recognized as there is a very lean difference between it and the psychomotor domain and as a result grouped as a single type of learning domain.

To be precise, the cognitive domain deals with the speed of thinking and recall, the affective domain deals with the improvement of character, while the psychomotor/psych-productive is involved with skills in practical work. Again each of these domains is subdivided into; lower, medium, and upper layers depending on complexity. For example, the cognitive domain is categorized into six: knowledge, comprehension, application, analysis, synthesis, and evaluation. Here, Knowledge and comprehension (lower cognitive domain), application and analysis (mid cognitive domain), and synthesis and evaluation as the upper cognitive domain. NOTE: the three broad categories of the cognitive domain- lower, mid, and upper is subject to the researcher, the actual Bloom taxonomy has only two major categories - the lower category made up of Knowledge, comprehension; and application with the upper category which consists of; analysis, synthesis, and evaluation.

Bloom's taxonomy is intended at serving educators recognize the intellectual height at which the various learners are competent of working (Rudnicki, 2018). On the whole, Bloom's taxonomy helps give confidence and teach students to make their own decisions just as in a classroom situation, but, also helps promote a life skill. In this wise an educator from the start of the teaching process should have the objective of the type of learning to be developed in the child (learner), such as mental skills (cognitive learning), improvement of thoughts or emotion (affective learning), and/or practical skills (psychomotor learning) [https://www.uen.org > bloom]. Teaching pedagogies therefore in the lower primary school (primary 1 - 6) aim at achieving the lower cognitive domains, as a result, primary $1-6$ pupils are taught and examined with the objective of knowledge and comprehension, the upper primary school (primary 7 - 9) which is the Junior Secondary Schools are examined with questions to cover the lower and mid cognitive domain, that is, knowledge, comprehension, application, and analysis (lower and mid cognitive domain) at a ratio of 60: 40. Questions for the senior secondary are expected to cover all the areas of the cognitive domain at a ratio of 40: 35: 25 or 60: 40 using the actual bloom taxonomy classification of lower and upper categories in line with the complexity. Summarily, though Bloom taxonomy does not deal with plants' classification, it is significant in aiding intellectual growth as an organizational ladder which classifies thinking skills starting with the recall of information as the simplest skill, to evaluation, which includes adjudicating and stating a view about specific information essential for both teachers and examiner to generate lesson plans (Rudnicki, 2018) and test items for the learners.

\section{Examination Bodies in Nigeria}

There are diverse Examination Bodies in Nigeria, each of these bodies has its function. The most important ones are; West African Examinations Council (WAEC), National Examinations Council (NECO), National Business 
and Technical Examinations Board (NABTEB), and Joint Admissions and Matriculation Board (JAMB). Each of these bodies makes effort to fulfill its obligations (https://iaea.info/documents/big-)data-generated-byexamination-bodies-in-Nigeria-any-alternative-purposes). There are other examinations bodies such as the various ministries of education -Local, State, and Federal; that are involved in promotion tests, placement tests, and/or certificate tests for the lower and upper Primary Schools (Primary 6 and Primary 9 popularly called: First School Leaving Certificate Examination (FSLCE) and Junior School Certificate Examination (JSCE). Generally, the most important of the three learning categories is the cognitive domain.

\subsection{Function of WAEC}

As clearly stated in WAEC website; the West African Examinations Council (WAEC) is an examination board recognized and established by law since 1952 to control and regulates the examinations useful in the public interest in all the West African English-speaking countries in post-primary institutions, to conduct the examinations and to award certificates corresponding to those of equal examining bodies in other parts of the world (www.waecdirect.org).

WAEC conducts her examinations in two forms, namely: West African Senior School Certificate Examinations (WASSCE) simply called Senior School Certificate Examinations (SSCE) and WAEC private examinations simply called WAEC GCE, where the acronym GCE means "General Certificate Examination". The two different types of examination are valid and are of equal standard.

The Senior School Certificate Examination (SSCE) for School Candidates holds between May and June yearly, everything being equal. It is a type of achievement test taken by final year candidates in Senior Secondary Schools. The candidates wear their school uniforms. While the WAEC GCE was formerly conducted in November/December each year, but, with effect from 2018, takes place in two phases: the first sequence is conducted between January and February while the Second is conducted between August and October, everything being equal. This WAEC GCE examination is for private candidates simply called GCE, therefore, a uniform is not required. Both examinations (WAEC GCE and WASSCE) are standardized and are of equal value (Komsabi).

The WEAC examinations have the following core values: excellence, integrity, innovation, accountability, professionalism, transparency, .team work, and integrity (Komsabi).

\section{Educational domains covered by different examining bodies in Nigeria}

Normally, the WAEC and NECO are mostly concern with testing the cognitive domain in the post-primary schools; NABTEB is concerned with tests on the psychomotor domain (acquired skills) in secondary technical and tertiary technical schools while JAMB has the function of testing the aptitude of the learner for admission into the tertiary institutions in Nigeria. The above conception about WAEC, NECO, and NABTEB on providing achievement tests on specified domains for final year students in the post-primary schools is no longer admissible, as the three examination bodies now conduct tests and give out certificates in all subjects offered in the post-secondary schools in Nigeria. For instance, WAEC and NECO just like NABTEB, presently examine and give out certificates in carpentry, welding, and fabrication, mechanical engineering, electrical engineering, etc. an indication of lack of division of labor between the various examining bodies. This system if allowed to persist may result in loss of educational standard as competition for a candidate may arise and candidates begin to search for examination body they could easily pass her tests. A situation in which, the different examining bodies will sacrifice standards for profit.

Apart from testing the cognitive, affective, and or the psychomotor domain of the learner, the examiner should consider the level of learners taking the test, as this determines the thinking power of the testees. The verbs used in questions for the senior secondary schools are supposed to be more tasking than as compared to the verbs used for the junior secondary schools, which also is harder compared to the ones in the primary schools. For instance: a question on respiration, in primary school: define respiration? In the junior secondary: explain respiration? In senior secondary school: respiration is important to all living things. True or false, explain? The importance of this paper, therefore, is to estimate the degree to which the West African Senior School Certificate Examination (WASSCE) covers all the Subdivisions of the Cognitive Domain in English in each specific year? Specifically, the researcher seeks to estimate:

1. The extent the WAEC objective English questions in the year 2020 cover the lower cognitive domain?

2. The extent the WAEC objective English questions in the year 2020 cover the mid-cognitive domain?

3. The extent the WAEC objective English questions in the year 2020 cover the upper cognitive domain?

4. The extent the WAEC theory English questions in the year 2020 cover the lower cognitive domain?

5. The extent the WAEC theory English questions in the year 2020 cover the mid-cognitive domain?

6. The extent the WAEC theory English questions in the year 2020 cover the upper cognitive domain? 


\section{Research Hypotheses}

The research hypotheses below guided the study:

1. Hypothesis 1: The extent to which the WAEC objective English questions in the year 2020 cover the lower cognitive domain is not significant

2. Hypothesis 2: The extent to which the WAEC objective English questions in the year 2020 cover the mid-cognitive domain is not significant

3. Hypothesis 3: The extent to which the WAEC objective English questions in the year 2020 cover the upper cognitive domain is not significant

4. Hypothesis 4: The extent to which the WAEC theory English questions in the year 2020 cover the lower cognitive domain is not significant

5. Hypothesis 5: The extent to which the WAEC theory English questions in the year 2020 cover the mid-cognitive domain is not significant

6. Hypothesis 6: The extent to which the WAEC theory English questions in the year 2020 cover the upper cognitive domain is not significant

\subsection{Design and Procedure}

The researcher made use of the case study research design to arrive at her findings, through the use of an instrument designed by the West African Examinations Council (WAEC) and the full verb lists for writing educational objectives as a theoretical framework for the analysis. The population for this study was 276 which comprise of the entire past question papers in all the four core subjects (English, Mathematics, Integrated Science, and Social Studies [www.waec.org] since the inception of WAEC in Nigeria. study.

From this population of 276 past question papers, the question paper for the year 2020 was sampled for the

\subsection{Validity of Instrument}

The instrument for this study was regarded as valid because all the examination questions of WAEC are standardized and therefore valid. Also the full lists for writing educational objectives that guided the study were valid been standardized lists generally accepted by educators (https://www.google.com/search?biw=1583\&bih).

4.3 Data Presentation, Analysis, and Result

Table 1: Showed the Expected and the Observed Count domain Category in Objective and Theory

\begin{tabular}{llll}
\hline & \multicolumn{1}{c}{ CDC } & Expected & Observed \\
\hline Objective & Lower & 32 & --- \\
80 & Mid & 28 & 80 \\
Questions & Upper & 20 & --- \\
Theory & Lower & 11 & 27 \\
27 & Mid & 10 & --- \\
Questions & Upper & 6 & --- \\
Total & & 107 & 107 \\
\hline
\end{tabular}

$\mathrm{CDC}=$ Cognitive Domain Categories.

Note: all sub-questions in the theory were taken as independent questions.

Table 2: showed the total number of questions set under each category with the observed total questions in each category.

\begin{tabular}{lcccc}
\multicolumn{1}{c}{ Items } & Objective & Theory & Total \\
\hline Lower Cognitive & - & 27 & 27 \\
Mid Cognitive & 80 & - & 80 \\
Upper Cognitive & - & - & - \\
Total & 80 & 27 & 107 \\
\hline
\end{tabular}

Note: all sub-questions in the theory were taken as independent questions. 
Table 3: showed table 2 using only two categories (Lower \& Upper) according to Bloom

\begin{tabular}{lccc}
\hline Items & $\begin{array}{c}\text { Lower } \\
\text { Cognitive }\end{array}$ & Upper Cognitive & Total \\
\hline Objective & 80 & - & 80 \\
Theory & 27 & - & 27 \\
Total & 107 & - & 107 \\
\hline
\end{tabular}

Table 4: Summary of Chi-Square Test, to test hypotheses

\begin{tabular}{crrrrrl}
\hline Item & Objective & Theory & Total & \multicolumn{2}{l}{ Pearson Chi-Square } & \\
\hline Lower & & 27 & 27 & Value & df & Asymptotic \\
Mid & 80 & & 80 & $12.188^{\text {a }}$ & 1 & $\begin{array}{l}\text { Significance } \\
(2 \text {-sided) } \\
\text { Total }\end{array}$ \\
& 80 & 27 & 107 & & & .000 \\
\hline
\end{tabular}

a. $\quad 0$ cells $(0.0 \%)$ have expected counts less than 5 .

The minimum expected count is 6.81 . Computed only for a $2 \times 2$ table

Hypothesis 1: The extent to which the WAEC Objective English questions in the year 2020 cover the Lower cognitive domain is not significant?

From table 1, 32 objective questions are expected in the lower cognitive category, but, tables $2,3 \& 4$ showed that no questions were in this category. Table 4 further showed a Pearson Chi-Square of $12.188,1$ degree of freedom (df), and a p-value (asymptote significant value [2-sided] of .000). Therefore, the null hypothesis as stated above is rejected, that is, $x^{2}(1, \mathrm{~N}=107)=12.188, \mathrm{P}<.01$

Hypothesis 2: The extent to which the WAEC Objective English questions in the year 2020 cover the midcognitive domain is not significant?

From table 1, 28 objective questions are expected in the mid-cognitive category, but, tables $2,3 \& 4$ showed that 80 questions were set in this category. Table 4 further showed a Pearson Chi-Square of 12.188, 1 degree of freedom (df), and a p-value (asymptote significant value [2-sided] of .000). Therefore, the null hypothesis as stated above is rejected, that is, $x^{2}(1, \mathrm{~N}=107)=12.188, \mathrm{P}<.01$

Hypothesis 3: The extent to which the WAEC Objective English questions in the year 2020 cover the upper cognitive domain is not significant?

From table 1, 20 objective questions are expected in the upper cognitive category, but, tables $2,3 \& 4$ showed that no question was set on this category. Table 4 further showed a complete absence of the upper cognitive category, hence a footnote: "The minimum expected count is 6.81 . Computed only for a 2 x 2 table" the computation should have been for a $3 \times 3$ table. Therefore, the null hypothesis as stated above is rejected, that is, $x^{2}(1, \mathrm{~N}=107)=12.188, \mathrm{P}<.01$

Hypothesis 4: The extent to which the WAEC theory English questions in the year 2020 cover the lower cognitive domain is not significant?

From table 1, 11 (eleven) theory questions are expected in the lower cognitive category, but, tables $2,3 \& 4$ showed that 27 questions were in this category. Table 4 further showed a Pearson Chi-Square of 12.188, 1 (one) degree of freedom (df), and a p-value (asymptote significant value [2-sided] of .000). Therefore, the null hypothesis as stated above is rejected, that is, $\boldsymbol{x}^{2}(1, \mathrm{~N}=107)=12.188, \mathrm{P}<.01$

Hypothesis 5: The extent to which the WAEC theory English questions in the year 2020 cover the midcognitive domain is not significant?

From table 1, 10 theory questions are expected in the lower cognitive category, but, tables $2,3 \& 4$ showed that no questions were in this category. Therefore, the null hypothesis as stated above is rejected, that is, $x^{2}$ ( 1 , $\mathrm{N}=107)=12.188, \mathrm{P}<.01$

Hypothesis 6: The extent to which the WAEC theory English questions in the year 2020 cover the upper cognitive domain is not significant?

From table 1, six (06) theory questions are expected in the upper cognitive category, but, tables $1,2 \& 4$ showed that no questions were in this category. Therefore, the null hypothesis as stated above is rejected, that is, $\boldsymbol{x}^{2}(1, \mathrm{~N}=107)=12.188, \mathrm{P}<.01$

\section{Discussion on findings}

The findings showed that the West African Senior School Certificate Examinations (WASSCE) conducted by the West African Examinations Council (WAEC) are at variance with Jean Piaget's theory of Cognitive 
development and with the Benjamin Bloom Taxonomy of learning. Jean Piaget in their theory of cognitive development believed that cognitive learning/development in the child/learner starts from simple to complex (simplypsychology.org/). In line with this theory, Benjamin Bloom developed their learning domain and categorized same into two major categories: lower and upper beginning from simple to complex. By this, it is expected that the tests presented to the learner should indicate the category of learner. Flowing from table 3 , the entire test skewed to and is in the lower category, that is, questions; which are meant for primary and upper primary schools (grade 1 - 9).

The primary and secondary educations in Nigeria and in most parts of the world subdivide learning progress into three stages: Lower Primary, Upper Primary, and Senior Secondary School or Primary, Junior Secondary, and Senior Secondary School. Therefore, the investigators have re-subdivided the categories of cognitive learning by Bloom into three: lower, mid, and upper (as against two: lower and upper), and find out that the WASSCE as found in the English questions of 2020 do not cover the Senior Secondary Schools, but, the Primary and the Junior Secondary Schools (upper primary school)- a contradiction to both the Piaget theory of Cognitive Development and to the Bloom taxonomy of cognitive learning. This finding is in line with the work of Claudia et al who find out that the cognitive levels of learning objectives are tilted to the lower order rational skills recovery and understanding in syllabi of the three major science subjects: biology, chemistry, and physics (Claudia, Helen, \& Maree, 2021). This type of situation where both the syllabi and the test questions are in the lower domain reduces the quality of teaching and learning with a resultant effect of quality of education output.

\section{Suggestions}

1. All examination bodies should consider the Bloom taxonomy of cognitive learning during test development.

2. Questions required to test and certify senior secondary school learners should cover the lower, mid, and upper cognitive domains of learning.

3. Some levels of complex questions in the Senior School Certification Tests is essential to propel teachers to work harder and learners to improve on their study habit.

4. The different examining bodies in Nigeria- WAEC, NECO, and NABTEB should be specific on the type of examination to conduct and give certificate (either cognitive, affective, or psychomotor). This is to avoid the loss of educational standards and competition for candidates.

5. Cognitive Learning Domains to be categorized into three: lower, mid, and upper as against just lower and upper.

\section{References}

Armstrong, P. (2010). Bloom taxonomy. https://cft.vanderbilt.edu/guides-sub- pages/blooms-taxonomy.

Claudia J, Helen B, \& Maree D.,T. (2021). Cognitive Demands of the Reformed Queensland Physics, Chemistry, and Biology Syllabus: An Analysis Framed by the New Taxonomy of Educational Objectives. https://link.springer.com/article/10.1007/s11165-021-09988-4

Bloom Taxonomy in the classroom: https://www.uen.org > bloom.

https://iaea.info/documents/big-data-generated-by-examination-bodies-in-Nigeria-any-alternative-purposes.

Full verb lists for educational objectives. https://www.google.com/search?biw=1583\&bih.

What is the benefits of using Bloom Taxonomy? https://classroom.synonym.com/benefit-using-bloomstaxonomy-6749935.html

Everything you should know about WAEC, SSCE, and GCE. http://komsabi.com/article/waec/everything-youshould-know-about-waec-ssce-gce.

Rudnick, A.(2018).Bloom taxonomy https://www.mvorganizing.org

Piaget's Theory and Stages of Cognitive Development. https://www.simplypsychology.org/piaget.html

How many subjects are there in WAEC? www.waec.org. 